\title{
Evaluasi Derajat Homogenisasi (Homodegree) dan Korelasinya dengan Ukuran Partikel Lemak Susu Sterilisasi Komersil
}

\section{The Evaluation of Homogenization Degree (Homodegree) and its Correlation with Milk Fat Particle Size of Sterillized Milk}

\author{
Azis Boing Sitanggang ${ }^{1,2)^{*}}$, Azizah Luthfiyah Assa'adiyah ${ }^{1)}$, Dahrul Syah ${ }^{1)}$ \\ ${ }^{1)}$ Departemen Ilmu dan Teknologi Pangan, Fakultas Teknologi Pertanian, Institut Pertanian Bogor, Bogor \\ ${ }^{2}$ South East Asian Food and Agricultural Science and Technology Center, Institut Pertanian Bogor, Bogor
}

\begin{abstract}
Homogenization is one of the key processes in the production of UHT milk. This process is designed to reduce the size of fat globule, thus decreases the possibility of milk fat separation during storage. To ease the monitoring of successful homogenization process, homogenization degree (homodegree, ${ }^{\circ} \mathrm{H}$ ) is commonly used instead of direct measurement of fat globule size using particle size analyser (PSA). This study was aimed to investigate the correlation between the resulted homodegree and the results of particle size analysis using PSA. There were two UHT milk variants used, A and B. Within this study, UHT milk fat globule of variant A dan B had mean diameter of $0.314 \pm 0.020 \mu \mathrm{m}$ and $0.228 \pm 0.005 \mu \mathrm{m}$, respectively. By this, a higher value of ${ }^{\circ} \mathrm{H}$ was resulted from UHT milk variant $A$. The homodegree was sensitive respective to the change of particle size of UHT milk for each variant. Additionally, homodegree was found to have a poor correlation, i.e., based on coefficient of determination $\left(R^{2}\right)$ especially for smaller size of fat globules $\left(d_{10}\right)$. However, this correlation was evaluated to increase for larger fat globules $\left(d_{50}, d_{90}\right)$. Homodegree was also found to have poor correlation either with pressure or inlet temperature applied in homogenization. Despite some miscorrelation found between the homodegree and pressure or temperature of homogenization, measuring homodegree below 13.5 was still found sufficient to indicate successful homogenization in which UHT milk fat globule size was below 0.4 $\mu m$.
\end{abstract}

Keywords: fat globule, homodegree, homogenization, particle size analysis, UHT milk

\begin{abstract}
Abstrak. Salah satu produk olahan susu di Indonesia adalah susu Ultra High Temperature (UHT). Homogenisasi merupakan salah satu proses utama dalam produksi susu UHT. Proses ini dirancang untuk mengecilkan ukuran globula lemak, sehingga mengurangi kemungkinan pemisahan lemak susu selama masa penyimpanan susu UHT. Untuk memudahkan evaluasi proses kecukupan homogenisasi, pengukuran derajat homogenisasi (homodegree, ${ }^{\circ} \mathrm{H}$ ) biasanya digunakan sebagai pengganti dari pengukuran langsung besaran ukuran partikel lemak susu. Penelitian ini bertujuan mengetahui hubungan antara ukuran partikel hasil analisis menggunakan particle size analyser (PSA) dengan nilai dari homodegree. Terdapat dua (2) varian susu UHT yang digunakan dari perusahaan XYZ, yakni varian A dan B. Dalam penelitian ini, globula lemak susu UHT dari varian A dan B memiliki diameter rata-rata $0.314 \pm 0.020 \mu \mathrm{m}$ dan $0.228 \pm$ $0.005 \mu \mathrm{m}$. Hal ini dapat secara langsung mengindikasikan bahwa nilai ${ }^{\circ} H$ yang lebih tinggi untuk susu UHT varian A. Homodegree bersifat sensitif terhadap perubahan ukuran partikel susu UHT untuk setiap varian. Pada penelitian ini, homodegree memiliki korelasi yang rendah (berdasarkan koefisien determinasi $\left(R^{2}\right)$ terutama untuk lemak susu berukuran kecil $\left(d_{l 0}\right)$. Namun, korelasi ini seiring meningkat seiring dengan membesarnya ukuran globula lemak $\left(d_{50}, d_{90}\right)$. Homodegree juga memiliki korelasi yang rendah baik dengan tekanan ataupun suhu inlet homogenisasi. Meskipun demikian, pengukuran homodegree dengan nilai di bawah 13,5 masih dapat digunakan untuk menunjukkan keberhasilan proses homogenisasi karena ukuran globula lemak susu UHT baik varian A dan B masih di bawah $0.4 \mu \mathrm{m}$.
\end{abstract}

Kata Kunci: analisis ukuran partikel, globula lemak, homodegree, homogenisasi, susu UHT

Aplikasi Praktis: Hasil penelitian ini dapat digunakan sebagai dasar, dan sebagai pilihan metode dalam
aktivitas quality control ukuran globula lemak susu pada industri minuman susu, baik yang diproses secara
pasteurisasi maupun sterilisasi.

\section{PENDAHULUAN}

Susu steril komersial ultra high temperature (susu UHT) merupakan produk susu cair yang diolah dengan

Korespondensi: boing.lipan@gmail.com pemanasan pada suhu tinggi, dan dikombinasikan dengan sistem pengemasan aseptik (Cattaneo et al. 2008). Suhu proses yang digunakan pada pemanasan susu UHT umumya berkisar $130-150^{\circ} \mathrm{C}$ dengan waktu pemanasan pada holding tube dalam beberapa detik (Tomasula et al. 2016). Waktu yang singkat pada proses 
pemanasan UHT dilakukan untuk mencegah kerusakan komponen gizi susu untuk mendapatkan warna, aroma, dan rasa yang relatif tidak berubah (Cattaneo et al. 2008). Konsumsi susu di tahun 2008-2013 mengalami peningkatan sebesar $8.3 \%$, dan hal ini masih menunjukkan tren yang positif untuk tahun-tahun berikutnya (Santoso et al. 2015). Untuk tetap mempertahankan penerimaan produk susu, khususnya susu UHT, maka keamanan dan kualitas produk akhir harus tetap dijaga, dan salah satunya terkait dengan ukuran globula lemak susu UHT.

Salah satu unit operasi yang penting dalam menjaga mutu dari susu UHT adalah proses homogenisasi. Homogenisasi dapat didefinisikan sebagai proses pencapaian homogenitas suatu produk dengan memodifikasi ukuran partikel (Dhankhar 2014). Pada susu UHT ataupun susu cair lainnya, homogenisasi adalah proses mekanis yang digunakan untuk mengurangi ukuran globula atau partikel lemak alami susu dengan memompa susu pada tekanan tinggi (15-40 $\mathrm{MPa})$ melalui katup kecil. Proses pemecahan partikel lemak (rata-rata diameter sekitar $3.5 \mu \mathrm{m}$ ) menjadi partikel yang jauh lebih kecil (diameter $<1 \mu \mathrm{m}$ ) diharapkan dapat mencegah fenomena creaming pada susu UHT ataupun produk susu cair lainnya selama penyimpanan (Qi et al. 2015). Pada susu UHT, proses homogenisasi ini menjadi sangat penting mengingat umur simpannya yang relatif lama. Dengan demikian, pada industri pengolahan susu UHT, ukuran partikel lemak merupakan parameter yang diamati atau diukur oleh disivi quality control (QC) untuk mengkonfirmasi kesuksesan dari proses homogenisasi yang dilakukan.

Distribusi ukuran partikel atau globula dalam suatu sampel dapat ditentukan dengan menggunakan prinsip difraksi laser, yakni berupa instrumen particle size analyser (PSA). Alat ini menghasilkan dan mentransmisikan sinar laser yang melewati larutan sampel dalam kuvet. Cahaya akan tersebar dan diserap, tergantung pada ukuran, indeks bias dan jumlah partikel dalam sampel (Edén et al. 2016, Oort et al. 2016). Hasilnya disajikan sebagai kurva distribusi ukuran. Persentase volume (lemak) diberikan sebagai fungsi dari ukuran partikel (ukuran globula lemak). Pada umumnya, terdapat beberapa parameter ukuran partikel yang dihasilkan, yakni ukuran diameter rataan, $d_{(4,3)}$ (average volume-weighted diameter $), d_{10}, d_{50}$ dan $d_{90}$. Beberapa faktor yang harus diperhatikan dalam proses homogenisasi menggunakan tekanan adalah tekanan pda fase ke-1 dan ke-2 dari homogenizer, suhu inlet susu, maupun kandungan lemak pada susu tersebut (Truong et al. 2016). Ukuran globula lemak semakin berkurang atau mengecil pada tekanan yang lebih tinggi, tetapi efek homogenisasi pada pengecilan ukuran globula lemak berkurang ketika kandungan lemak pada susu tinggi (Biasutti et al. 2009).

Pada perusahaan XYZ, pengukuran kecukupan proses homogenisasi susu UHT dilakukan menggunakan alat homodegree meter (Globuliser, Lactotronic, Netherlands). Homodegree adalah angka tanpa dimensi yang berhubungan dengan derajat homogenisasi produk susu dengan nilai maksimum yang diterima adalah 13.5 (spesifikasi PT XYZ). Dengan demikian, homodegree $\left({ }^{\circ} \mathrm{H}\right)$ secara tidak langsung dapat mengindikasikan pengecilan ukuran globula lemak setelah proses homogenisasi. Evaluasi kecukupan proses homogenisasi dengan homodegree meter dipilih karena waktu yang dibutuhkan untuk mengevaluasi proses homogenisasi lebih cepat, dan proses pengukurannya lebih sederhana dibandingkankan dengan pengukuran globula lemak menggunakan PSA. Dalam penelitian ini, evaluasi proses homogenisasi berdasarkan homodegree, dan mengkorelasikannya dengan hasil pengukuran menggunakan PSA dilakukan dengan tujuan meminimalisir kesalahan dalam pengambilan keputusan atas kondisi proses homogenisasi. Selain itu, informasi yang didapat digunakan sebagai acuan untuk mengkalibrasi homodegree meter yang ada.

\section{BAHAN DAN METODE}

\section{Bahan dan alat}

Bahan yang digunakan dalam penelitian ini adalah susu UHT PT XYZ varian A dan B, etil diamina tetra asetat (EDTA), dan akuades. Alat yang digunakan adalah homodegree meter (Globuliser, Lactotronic, Netherlands), laser diffraction particle size analyser (PSA) LS13320 (Beckman Coulter, Canada), dan peralatan gelas lainnya.

\section{Pengambilan data}

Data yang digunakan dalam penelitian ini terdiri dari dua jenis. Data primer berupa evaluasi proses homogenisasi susu UHT PT XYZ varian A dan B menggunakan homodegree meter dan PSA. Sampel yang akan dianalisis diambil dari lini proses produksi susu UHT sebelum produk dikemas, dan dari delapan batch yang berbeda. Kondisi proses homogenisasi untuk setiap sampel adalah sama sesuai dengan prosedur operasional baku produksi susu UHT pada PT XYZ, yakni tekanan homogenizer $=\sim 230$ bar, dan suhu inlet $=$ $\sim 85^{\circ} \mathrm{C}$. Sementara itu, data sekunder adalah berupa fluktuasi tekanan homogenizer, suhu inlet susu kedalam homogenizer, dan homodegree $\left({ }^{\circ} \mathrm{H}\right)$ produk akhir kedua varian susu UHT. Dalam hal ini, data sekunder susu UHT varian A diambil sebanyak 72 batch selama periode Juni 2016 sampai Maret 2017, dan untuk varian B sebanyak 44 batch pada periode April 2016 sampai Maret 2017.

\section{Analisis ukuran globula lemak susu}

Ukuran globula lemak susu UHT menggunakan PSA LS13320 (Beckman Coulter, Canada) sesuai dengan metode Lu et al. (2013). Sample sebanyak 1.75 dan $2.0 \mathrm{~mL}$ berturut-turut untuk varian $\mathrm{A}$ dan $\mathrm{B}$ dicampurkan dengan $100 \mathrm{~mL}$ akuades. Sebanyak $2.5 \mathrm{~mL}$ larutan EDTA dituang ke dalam masing-masing campuran lalu diaduk merata. Campuran didiamkan 
selama 1 menit dan dianalisis menggunakan PSA Dengan menggunakan perangkat lunak yang ada, parameter ukuran globula lemak yang diperoleh dapat berupa diameter rata-rata globula lemak $\left(d_{\text {mean }}\right), d_{10}, d_{50}$, dan $d_{90}$. Distribusi ukuran partikel $d_{10}$ menunjukkan sebanyak $10 \%$ partikel lemak berukuran lebih kecil dari nilai $d_{10}$, dan distribusi ukuran partikel $d_{50}$ menunjukkan sebanyak $50 \%$ partikel lemak berukuran lebih kecil atau lebih besar dari $d_{50}$ dan demikian selanjutnya untuk $d_{90}$ (Di Marzo et al. 2016). Analisis dilakukan sebanyak tiga kali ulangan.

\section{Analisis homodegree $\left({ }^{\circ} \mathrm{H}\right)$}

Analisis homodegree $\left({ }^{\circ} H\right)$ mengacu kepada instruksi kerja Lactotronic BV, Netherlands. Analisis diawali dengan pengecekan sumber sinar dengan rentang pembacaan sekitar 150-210 unit. Jika pembacaan berada diluar rentang nilai, maka pembersihan lensa dan lampu dilakukan menggunakan alkohol. Selanjutnya, starting point length (L) ditetapkan pada layar hingga mencapai nilai 180 unit tanpa memasukkan kuvet, lalu slide dinaikkan sehingga scattering value $(\mathrm{S})$ dapat dimonitor. Kuvet yang telah berisi akuades dimasukkan, lalu slide dinaikkan sehingga water value (W) dibaca dan persen (\%) kejernihan dapat dikalkulasi sebagai berikut:

$$
\% \text { Kejernihan }=\frac{\mathrm{W}-\mathrm{S}}{\mathrm{L}} \times 100 \%
$$

Apabila nilai persen kejernihan melebihi 6\%, maka kemungkinan kuvet yang digunakan kotor atau tergores, atau akuades mengandung partikel tersuspensi (terkontaminasi). Pengukuran homodegree dilakukan dengan menambahkan sampel susu UHT sebanyak 1.9$2.1 \mathrm{~mL}$ kedalam $100 \mathrm{~mL}$ akuades, dan $0.2 \mathrm{~mL}$ EDTA ditambahkan, lalu campuran diaduk, dan didiamkan selama 1 menit. Analisis dilakukan sebanyak tiga kali ulangan dan homodegree $\left({ }^{\circ} \mathrm{H}\right)$ dihitung dengan:

$$
\begin{aligned}
\mathrm{Q} & =\frac{T \times 10 \times W}{\mathrm{~L} \times 9} \\
{ }^{\circ} \mathrm{H} & =\frac{(\mathrm{S}-\mathrm{Q})}{\mathrm{L}} \times 26
\end{aligned}
$$

Keterangan: $T$ (Transmission value $)=$ nilai transmisi cahaya sampel, $W($ Water value $)=$ nilai trasmisi cahaya air, $L$ (Length wise $)=$ sudut kemiringan cahaya, $Q$ (False light correction $)=$ nilai koreksi terhadap cahaya, $S$ (Scattering value $)=$ nilai sebar cahaya dan ${ }^{\circ} \mathrm{H}$ (Homodegree $)=$ derajat homogenisasi.

\section{HASIL DAN PEMBAHASAN} Korelasi antara derajat homogenisasi $\left({ }^{\circ} \mathrm{H}\right)$ dengan
ukuran globula lemak susu menggunakan PSA

Pada perusahaan PT XYZ, jika hasil pengukuran derajat homogenisasi $\left({ }^{\circ} \mathrm{H}\right)$ menggunakan homodegree meter menunjukkan angka $\leq 13.5$ maka proses homogenisasi berlangsung dengan baik sehingga ukuran globula susu berada di bawah $1 \mu \mathrm{m}$ (Qi et al. 2015), lebih tepatnya di bawah $0.4 \mu \mathrm{m}$ (sesuai dengan spesifikasi perusahaan PT XYZ). Hubungan antara nilai ${ }^{\circ} H$ dengan ukuran globula lemak susu UHT varian A (Gambar 1) dan varian B (Gambar 2).

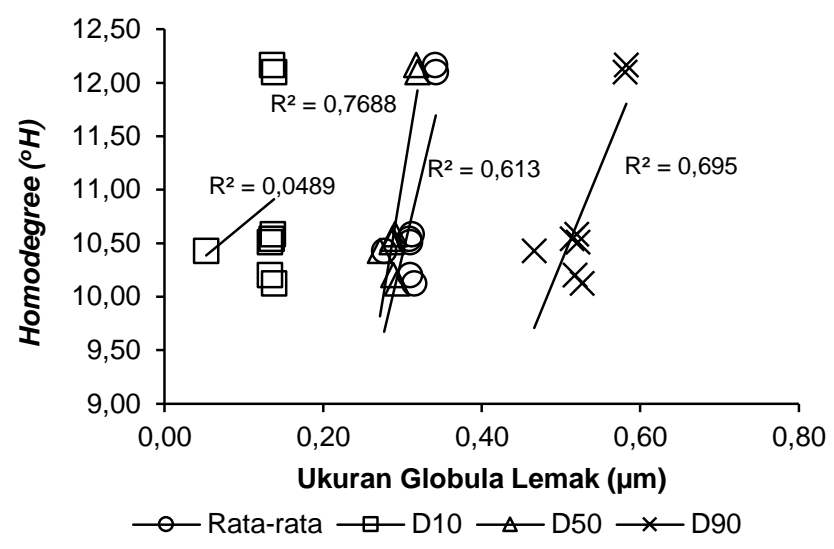

Gambar 1. Hubungan homodegree dengan ukuran globula lemak susu UHT varian A

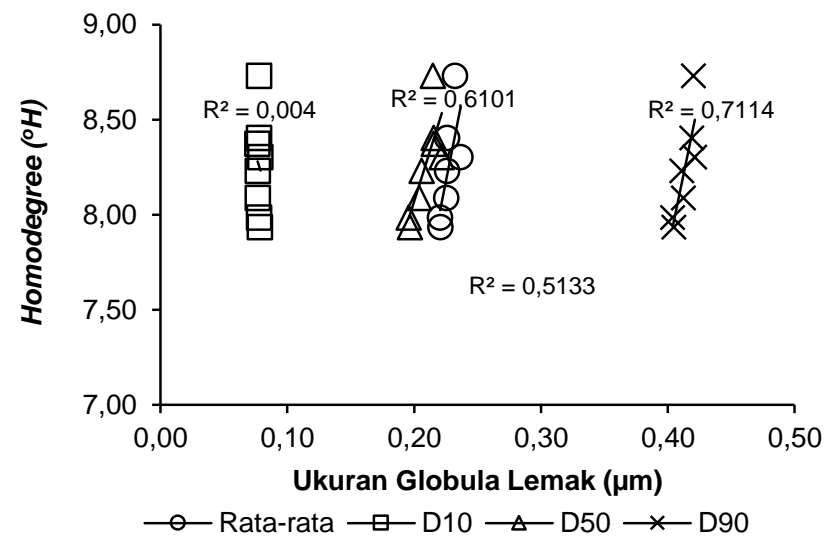

Gambar 2. Hubungan homodegree dengan ukuran globula lemak susu UHT varian B

Gambar 1 dan 2 menunjukkan pengukuran ${ }^{\circ} H$ bersifat sangat sensitif. Perubahan kecil yang terjadi pada ukuran globula lemak susu UHT dapat mengakibatkan perubahan nilai ${ }^{\circ} H$ cukup besar. Susu UHT varian A umumnya memiliki ukuran globula lemak ratarata lebih besar $(0.314 \pm 0.020 \mu \mathrm{m})$ jika dibandingkan varian B $(0.228 \pm 0.005 \mu \mathrm{m})$. Ukuran globula lemak susu tanpa proses homogenisasi mencapai $15 \mu \mathrm{m}$ (ArgovArgaman 2019). Maka proses homogenisasi susu UHT varian A dan B berhasil dilakukan karena dapat mereduksi ukuran globula lemak susu menjadi 1.52$2.09 \%$ dari ukuran semula. Dengan ukuran globula lemak susu yang lebih besar pada susu UHT varian A, maka nilai ${ }^{o} H$-nya lebih besar dibandingkan susu UHT varian B. Dengan kondisi homogenisasi yang sama di PT XYZ (tekanan homogenizer=230 bar dan suhu inlet $=85^{\circ} \mathrm{C}$ ), masih terdapat perbedaan ukuran globula lemak antara susu UHT varian A dan B. Hal ini dapat sebabkan oleh faktor-faktor berupa sumber, jenis, dan komposisi ingredien penyusun kedua varian susu UHT tersebut, serta interaksi yang terjadi diantara komponen pangan susu selama proses pengolahan (Argov et al. 2008). Sebagai contoh, ukuran globula lemak susu kerbau umumnya lebih besar dibandingkan dengan susu kambing (Attaie dan Richter 2010). 
Logan et al. (2014) melaporkan bahwa variasi pada ukuran globula lemak susu dapat terjadi karena interaksi antara globula lemak susu dengan membran globula lemak susu, dan protein susu.

Korelasi antara nilai ${ }^{o} H$ dengan ukuran globula lemak $d_{10}, d_{50}, d_{90}$, dan $d_{\text {mean }}$ (diameter rata-rata) dapat dilihat Gambar 1 dan 2, serta nilai koefisien determinasinya $\left(R^{2}\right)$ disajikan pada Tabel 1 . Seperti yang telah diindikasikan sebelumnya bahwa nilai ${ }^{\circ} H$ bersifat sangat sensitif terhadap perubahan ukuran globula lemak. Perubahan kecil pada ukuran globula lemak baik pada parameter $d_{10}, d_{50}, d_{90}$, dan $d_{\text {mean }}$ dapat mengakibatkan perubahan yang sangat besar pada nilai ${ }^{\circ} H$. $\mathrm{Hal}$ ini terlihat dengan jelas terutama pada parameter $d_{10}$ untuk kedua varian susu UHT. Korelasi yang didapatkan sangat kecil dengan nilai $R^{2}=0.0489$ dan 0.004 berturut-turut untuk varian A dan B. Akan tetapi, korelasi positif dan semakin membesar antara antara nilai ${ }^{\circ} \mathrm{H}$ dengan ukuran globula lemak terjadi pada parameter $d_{50}, d_{90}$, dan $d_{\text {mean }}$. Hal ini dapat mengindikasikan bahwa alat homodegree meter akan semakin akurat untuk mengukur keberhasilan proses homogenisasi ketika ukuran globula lemak membesar dan mendekati nilai $1 \mu \mathrm{m}$.

Tabel 1. Hubungan antara ukuran globula lemak susu UHT varian $\mathrm{A}$ dan $\mathrm{B}$ dengan derajat homodegree $\left({ }^{\circ} \mathrm{H}\right)$

\begin{tabular}{cccc}
\hline $\begin{array}{c}\text { Susu } \\
\text { UHT } \\
\text { Varian }\end{array}$ & $\begin{array}{c}\text { Parameter } \\
\text { Ukuran } \\
\text { Partikel } /{ }^{\circ} \boldsymbol{H}\end{array}$ & $\begin{array}{c}\text { Koefisian } \\
\left.\text { Determinasi }\left(\boldsymbol{R}^{2}\right)^{*}\right)\end{array}$ & Rataan $(\boldsymbol{\mu m})$ \\
\hline Varian & $d_{10}$ & 0.0489 & $0.125 \pm 0.032$ \\
$\mathrm{~A}$ & $d_{50}$ & 0.6101 & $0.294 \pm 0.016$ \\
& $d_{90}$ & 0.695 & $0.529 \pm 0.036$ \\
& $d_{\text {mean }}$ & 0.613 & $0.314 \pm 0.020$ \\
& ${ }^{\circ} \mathrm{H}$ & - & $10.83 \pm 0.81$ \\
Varian & $d_{10}$ & 0.004 & $0.078 \pm 0.001$ \\
B & $d_{50}$ & 0.6101 & $0.209 \pm 0.009$ \\
& $d_{90}$ & 0.7114 & $0.414 \pm 0.007$ \\
& $d_{\text {mean }}$ & 0.5133 & $0.228 \pm 0.005$ \\
\hline
\end{tabular}

Keterangan: ${ }^{*}$ Koefisien determinasi $\left(\mathrm{R}^{2}\right)$ antara parameter ukuran partikel $\left(d_{10}, d_{50}, d_{90}\right)$ dengan derajat homogenisai (homodegree)

\section{Hubungan antara tekanan dan suhu inlet proses homogenisasi dan nilai homodegree $\left({ }^{\circ} \mathrm{H}\right)$}

Sebagaimana telah diindikasikan sebelumnya, nilai maksimum homodegree berdasarkan standar perusahaan adalah 13.5. Semakin rendah nilai homodegree, semakin baik proses homogenisasi yang telah dilakukan. Nilai homodegree yang tinggi menunjukkan bahwa semakin banyaknya cahaya yang ditransmisikan di dalam larutan saat pengukuran menggunakan homodegree meter. Hal tersebut menunjukkan semakin banyak ruang kosong diantara globula lemak yang diakibatkan oleh semakin besarnya globula lemak susu dalam sampel.

Tekanan homogenisasi telah dilaporkan memiliki pengaruh yang positif terhadap pengecilan ukuran globula lemak (Dumay et al. 2013). Gambar 3 (a) dan (b) menunjukkan korelasi antara nilai ${ }^{\circ} H$ dengan variasi tekanan homogenizer (data sekunder). Korelasi yang didapatkan sangat lemah/rendah untuk kedua varian susu UHT. Dengan semakin tingginya tekanan homogenizer maka nilai ${ }^{\circ} \mathrm{H}$ seharusnya semakin mengecil.
Namun, berdasarkan Gambar 3 (a) dan (b), tren ini tidak didapatkan. Ukuran globula lemak semakin berkurang atau mengecil pada tekanan yang lebih tinggi, tetapi efek homogenisasi pada pengecilan ukuran globula lemak berkurang ketika kandungan lemak pada susu tinggi (Biasutti et al. 2009). Mercan et al. (2018) juga melaporkan bahwa peningkatan tekanan homogenisasi menjadi 500 bar, dapat menurunkan ukuran globula lemak $\left(d_{[3,2]}\right)$ konsentrat susu skim secara signifikan.
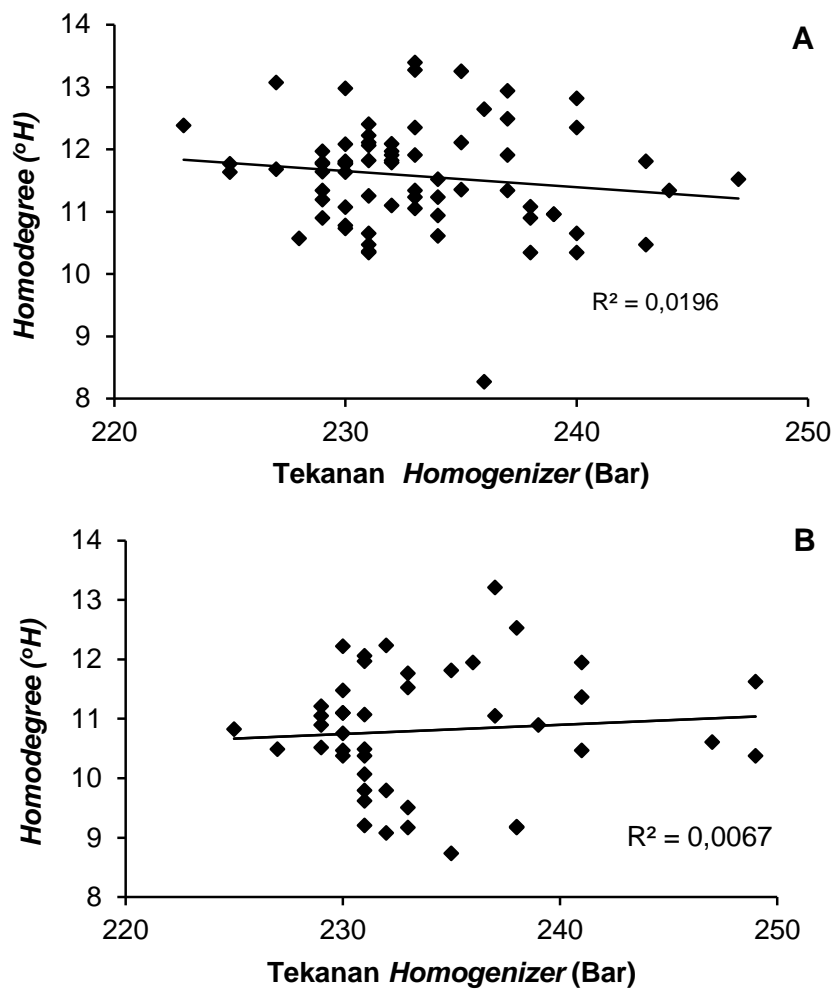

Gambar 3. Hubungan antara variasi tekanan homogenizer pada fase ke-1 dengan homodegree $\left({ }^{\circ} H\right)$ susu UHT varian A (a) dan varian B (b)

Proses homogenisasi dengan pressure homogenizer melalui dua fase. Fase ke-1 pada tekanan tinggi, lebih besar dari 150 bar (Dhankhar 2014). Hal ini bertujuan menghancurkan dan mengecilkan ukuran globula lemak. Fase ke-2, tekanan lebih rendah sekitar 30-40 bar bertujuan mencegah berkumpulnya globula-globula lemak kecil (clumping/clustering) karena menurunnya konsentrasi membran globula lemak dan protein susu (kasein) yang berfungsi mencegah coalescence diantara globula lemak susu kecil (Goff 2013, Wilde 2009). Dengan demikian, jika hanya mengkorelasikan variasi tekanan homogenisasi fase ke-1 dengan variasi nilai ${ }^{\circ} \mathrm{H}$ (Gambar 3(a) dan (b)), maka nilai koefisien determinasi $\left(R^{2}\right)$ menjadi kecil. Hal ini disebabkan kenaikan tekanan kedua fase homogenisasi memiliki peranan penting untuk pengecilan ukuran globula lemak. Evaluasi korelasi ${ }^{\circ} \mathrm{H}$ seharusnya dilakukan dengan profil tekanan homogenisasi pada fase ke-1 maupun ke-2.

Gambar 4 menunjukkan hubungan suhu inlet susu pada proses homogensiasi dengan ${ }^{\circ} \mathrm{H}$ susu UHT varian A (a) dan varian B (b). Suhu inlet susu sebelum masuk proses homogenisasi memiliki korelasi sangat rendah 
terhadap nilai ${ }^{o} H$ pada kedua varian susu UHT. Nilai $R^{2}$ 0.0545 untuk varian A dan 0.0004 varian B. Suhu inlet susu cukup tinggi pada proses homogenisasi sangat penting untuk menjaga fase lemak susu dalam bentuk cair dan tidak mengristal. Pengaruh kenaikan suhu terhadap ukuran globula lemak dapat diamati secara jelas ketika suhu inlet susu dinaikkan dari $40^{\circ} \mathrm{C}$ menjadi $50^{\circ} \mathrm{C}$ (Wiking dan Dickow 2013). Dengan suhu berbeda (55$85^{\circ} \mathrm{C}$ ), pada tekanan 2000 bar ataupun 3000 bar, hanya kenaikan sampai $75^{\circ} \mathrm{C}$ yang menunjukkan penurunan ukuran globula lemak sebagai fungsi kenaikan suhu (Juan et al. 2013). Dengan tekanan sama, suhu lebih tinggi $\left(85^{\circ} \mathrm{C}\right)$ globula lemak susu cenderung memiliki ukuran fluktuatif, yakni membesar atupun menurun.
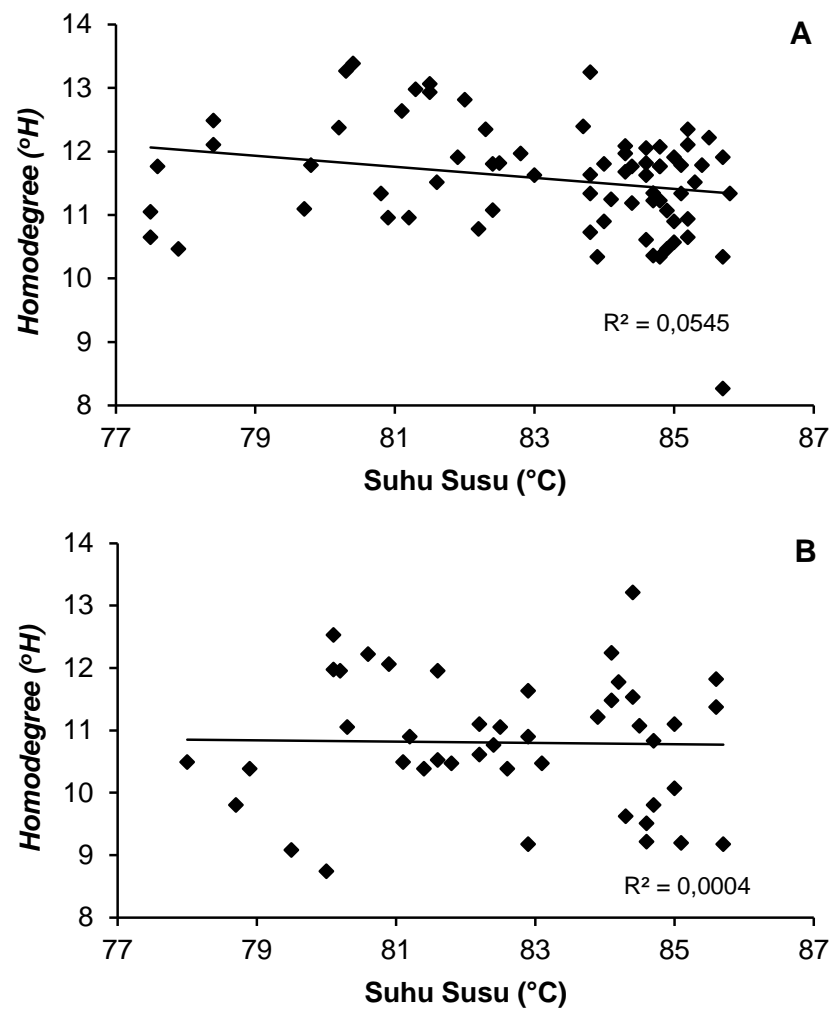

Gambar 4. Hubungan antara suhu inlet susu pada proses homogensiasi dengan homodegree $\left({ }^{\circ} \mathrm{H}\right)$ susu UHT varian A (a) dan varian B (b)

Hal ini karena pada suhu lebih tinggi $\left(>75^{\circ} \mathrm{C}\right)$, terdapat berbagai peristiwa yang terjadi secara acak pada katup homogenizer, seperti tabrakan kecepatan tinggi antar globula lemak, kavitasi, turbulensi yang mengakibatkan fenomena agregasi kembali globula lemak susu. Hal ini terjadi secara acak, sehingga ukuran globula lemak dapat mengecil ataupun membesar (Juan et al. 2013). Pada Gambar 3 (a) dan (b), fluktuasi suhu terjadi pada rentang $77-87^{\circ} \mathrm{C}$, dengan rentang tekanan homogensisasi fase ke-1 sebesar 220-250 bar. Dengan tingginya suhu inlet susu yang masuk ke homognizer maka pengaruhnya terhadap ukuran globula lemak berfluktuasi. Hal ini dapat mengakibatkan rendahnya korelasi antara suhu inlet susu dengan homodegree $\left({ }^{\circ} \mathrm{H}\right)$ dari kedua susu UHT di atas.

\section{KESIMPULAN}

Dengan mengevaluasi korelasi antara nilai homodegree $\left({ }^{\circ} \mathrm{H}\right)$ dengan berbagai parameter distribusi ukuran globula lemak susu UHT $\left(d_{10}, d_{50}, d_{90}\right.$, dan $\left.d_{\text {mean }}\right)$ untuk varian $\mathrm{A}$ dan $\mathrm{B}$, masih terdapat kelemahan pada evaluasi keberhasilan proses homogenisasi menggunakan nilai homodegree. Hal ini karena korelasi yang sangat rendah (nilai $R^{2}$ yang sangat kecil) untuk ukuran globula lemak mendekati $0.1 \mu \mathrm{m}\left(d_{10}\right)$. Namun, korelasi semakin besar jika ukuran globula lemak mendekati 1 $\mu \mathrm{m}$ (untuk $d_{50}, d_{90}$, dan $d_{\text {mean }}$ ). Korelasi antara homodegree dengan tekanan pada fase ke-1, atau dengan suhu inlet susu pada proses homogenisasi juga rendah. Hal ini disebabkan perlunya evaluasi tambahan atas besarnya tekanan pada fase ke-2 dari proses homogenisasi, dan berfluktuasinya ukuran globula lemak ketika suhu inlet berada di atas $75^{\circ} \mathrm{C}$. Meskipun demikian, pengukuran homodegree dengan nilai di bawah 13.5 masih dapat digunakan untuk menunjukkan keberhasilan proses homogenisasi karena ukuran globula lemak susu UHT baik varian A dan B masih di bawah $0.4 \mu \mathrm{m}$

\section{DAFTAR PUSTAKA}

Argov N, Lemay DG, German JB. 2008. Milk fat globule structure and function: nanoscience comes to milk production. Food Sci Technol 19(12): 617623. DOI: 10.1016/j.tifs.2008.07.006.

Argov N. 2019. Symposium review: Milk fat globule size: Practical implications and metabolic regulation. J Dairy Sci 102(3): 2783-2795. DOI: 10.31 68/jds.2018-15240.

Attaie R, Richter RL. 2010. Size distribution of fat globules in goat milk. J Dairy Sci 83(5): 940-944. DOI: 10.3168/jds.s0022-0302(00)74957-5.

Biasutti M., Spaziani M, Marchesini G, Venir E, Innocente N. 2009. Effect of high-pressure homogenization on droplet size distribution and rheological properties of ice cream mixes. J Dairy Sci 92(5): 1864-1875. DOI: 10.3168/jds.2008-1797.

Cattaneo S, Masotti F, Pellegrino L. 2008. Effects of overprocessing on heat damage of UHT milk. European Food Res Technol 226(5): 1099-1106. DOI: 10.1007/s00217-007-0637-5.

Dhankhar P. 2014. Homogenization fundamentals. IOSR J Engi 4(5): 01-08. DOI: h10.9790/302104540108 .

Di Marzo L, Cree P, Barbano DM. 2016. Prediction of fat globule particle size in homogenized milk using Fourier transform mid-infrared spectra 1. J Dairy Sci 99(11): 8549-8560. DOI: 10.3168/jds.201611284. 
Dumay E, Chevalier LD, Picart PL, Benzaria A, Gràcia JA, Blayo C. 2013. Technological aspects and potential applications of (ultra) high-pressure homogenisation. Food Sci Technol 31(1): 13-26. DOI: 10.1016/j.tifs.2012.03.005.

Edén J, Dejmek P, Löfgren R, Paulsson M, Glantz M. 2016. Native milk fat globule size and its influence on whipping properties. Inte Dairy J 61: 176-181. DOI: 10.1016/j.idairyj.2016.06.004.

Goff HD. 2013. Dairy product processing equipment. Dairy Food Machinery Eng 199-221. DOI: 10.1016/B978-0-12-385881-8.00009-4.

Juan B, Bárcenas ME, Suàrez BA, Trujillo AJ, Amador EG. 2013. Effect of moderate inlet temperatures in ultra-high-pressure homogenization treatments on physicochemical and sensory characteristics of milk. J Dairy Sci 97(2): 659-671. DOI: 10.316 8/jds.2013-7245.

Logan A, Auldist M, Greenwood J, Day L. 2014. Natural variation of bovine milk fat globule size within a herd. J Dairy Scie 97(7): 4072-4082. DOI: 10.3168/jds.2014-8010.

Lu C, Wang G, Li Y, Zhang L. 2013. Effects of homogenisation pressures on physicochemical changes in different layers of ultra-high temperature whole milk during storage. Int J Dairy Technol 66(3): 325-332. DOI: 10.1111/1471-0307.12055.

Mercan E, Sert D, Akın N. 2018. Effect of high-pressure homogenisation on viscosity, particle size, and microbiological characteristics of skim and whole milk concentrates. I Dairy J 87: 93-99. DOI: 10.1016/j.idairyj.2018.07.017.
Oort E, Van HB, Yang L, Hale A. 2016. Automated Drilling Fluid Analysis Using Advanced Particle Size Analyzers. In IADC/SPE Drilling Conference and Exhibition (pp. 1-9). Society Petroleum Engineers. DOI: 10.2118/178877-ms.

Qi PX, Ren D, Xiao Y, Tomasula PM. 2015. Effect of homogenization and pasteurization on the structure and stability of whey protein in milk. J Dairy Sci 98(5): 2884-2897. DOI: 10.3168/jds.2014-8920.

Santoso D, Najib M. 2015. Brand equity susu cair UHT dan pengaruhnya pada purchase intention. J Manajemen Agribisnis 12(1): 46-56. DOI: 10.1735 8/jma.12.1.46.

Tomasula PM, Bonnaillie L, Tunick MH, Van H, Paul M, Ren DX, Kwoczak R. 2016. Effect of heat and homogenization on in vitro digestion of milk. J Dairy Scie 99(6): 4124-4139. DOI: 10.3168/jds. 2015-10474.

Truong T, Palmer M, Bansal N, Bhandari B. 2016. Effect of milk fat globule size on the physical functionality of dairy products. Springer Int Publishing. DOI: 10.1007/978-3-319-23877-7

Wiking L, Dickow JA. 2013. Effect of homogenization temperature and pressure on lipoprotein lipase activity and free fatty acids accumulation in milk. Food Nutr Sci 04(08): 101-108. DOI: 10.423 6/fns.2013.48a013.

Wilde PJ. 2009. Emulsions and nanoemulsions using dairy ingredients. Dairy-Derived Ingredients 539564. DOI: $10.1533 / 9781845697198.3 .539$.

JMP-03-18-14-Naskah diterima untuk ditelaah pada 19 Maret 2018. Revisi makalah disetujui untuk dipublikasi pada 25 Februari 2019. Versi Online: http://journal.ipb.ac.id/index.php/jmpi 